\title{
The Relationships between Technology and Different Teaching Role Attributes of Instructors in Malaysia
}

\author{
Nurita Juhdi (Corresponding author) \\ Faculty of Business Administration, Tun Abdul Razak University \\ Jalan SS6/12, 47301, Kelana Jaya Selangor, Malaysia \\ Tel: 60-3-7627-7295 E-mail: nurita@unitar.edu.my
}

Ahmad Zohdi Abd Hamid

Faculty of Business, Al Hosn University

PO Box 38772, Abu Dhabi, United Arab Emirates

E-mail: a.zohdi@alhosnu.ae

Mohd Saeed bin Siddiq

Graduate School of Business, Tun Abdul Razak University

Capital Square, No. 8, Jalan Munshi Abdullah, 50100 Kuala Lumpur, Malaysia

E-mail: saeedbinsiddiq@unirazak.edu.my

Sponsor: Tun Abdul Razak University Malaysia

\begin{abstract}
The present study seeks to examine the influence of technology on these four roles. Two hundred and ninety two lecturers teaching in Malaysian tertiary educations were involved in this study. They were using different level of technologies for teaching. Questionnaires were used to solicit their responses which were distributed using various means; online, personal visits and regular mails. The measurement items were mainly adapted from Job Diagnostic Survey developed by Hackman and Oldham. The results from the findings revealed that technology was found giving significant positive impacts on technical and managerial roles. There is no evidence to support the significant influence of technology on the other two roles. The significant findings suggest that lecturers perceive their roles in managing the course and dealing with technical aspect of the job have been enhanced with the use of technology. However, the insignificant findings imply several major issues that are worth contemplating. The main implications of the study are discussed in terms of lecturers' teaching job design, training and performance appraisals.
\end{abstract}

Keywords: Technology, Education, Instructors, Job characteristics, Teaching roles

\section{Introduction}

Teachers' roles are becoming more demanding nowadays as they have to use various types of technology to aid the teaching and learning process. It is a fact that technology comes in various levels and features. Traditional instructional technology includes writing boards, writing tools and films; while new technology include computers, the internet and multimedia resources (Laurillard, 2006). In the past, numerous studies examining the use of new instructional technologies in education found mixed feelings and perceptions among instructors in tertiary education (Neo and Neo, 2009; Gratton-Lavoie and Stanley, 2009; Mitchell, 2009; Marlia, 2007; Agbonlahor, 2006; Hacifazlioglu, Sacli and Yengin, 2005; Ryan, Carlton and Ali, 2004; Hanson, 2003; Kewell and Beeby, 2003). These studies, however, did not explore how exactly the teaching job of instructors changed with the use of the technology. Teaching job is mainly made up of distinct roles that include course planning, designing, implementing and finally assessing students' progress. Each of these roles may differ in terms of autonomy, skill variety, feedback, significance and identity. Therefore, given the complexity in each role, examining the influence of technology on the whole teaching job is rather insufficient and 
thus warrant a specific study that looks into the smaller components that make up the teaching job. In the context of the present study, the smaller components of instructors' job are reflected in the form of teaching roles.

In measuring the impact of technology on different teacher roles, one important premise is the ability to operationalize the teacher roles using measurable constructs. The literature provides ample evidence of research done by scholars identifying distinct roles of teachers. Among the important roles discussed in the literature revolves around four major ones: pedagogical, managerial, technical and subject-designing (Berge, 2008; Ryan, Carlton and Ali, 2004; Bennet and Lockyer, 2004; Jaffee, 2003; Barker, 2002; Goodyear, Salmon, Spector, Steeples and Tickner, 2001). Thus far, there were no empirical studies to assess these roles attributes. In the present study, in line with the objective to measure the distinct characteristics of each role, validated measurement instruments are used to operationalize all the four teacher roles. Ultimately, this study aimed to examine the relationships between technology level used by instructors and their teaching roles in order to determine the extent of technology influence on teaching job.

\section{Literature Review}

\subsection{Technology and Job Attributes}

Prior research showed mixed findings on the impacts of technology on employees' work attributes. In their studies, Bartel et al (2007) indicated technology has positive influence on employees' skill requirements particularly in technical and problem solving skills. However, there are studies that found contradicting results. Technology has been cited a significant factor that reduce the degree of job characteristics mainly in skill and autonomy (Feldberg and Glenn, 1987; Kraft, 1977; Shaiken, 1984; Zimbalist, 1979; Menzies, 1982; Glenn and Feldberg, 1977; Braverman, 1974).

In the education arena, instructors have been reported as being optimistic with the technology potential to enhance their teaching practice quality (Shen et al, 2008; Siragusa and Dixon, 2006; Ryan et al, 2004) despite their positive and negative comments about technology impact on their job (Marlia, 2007; Hacifazlioglu et al, 2005; Poon et al, 2004). Given the inconsistency in the influence of technology on job characteristics, it is interesting to examine the impact on instructors who are using different levels of technology that range from low to high level sophistication. More importantly, it is pertinent to find out whether technology has different degree of impact on the four major roles which are proposed as unique from each other.

\subsection{The Roles of Instructors}

The literature on the roles of instructors/teachers revolves around four major ones; pedagogical, managerial, technical and subject designing (Ryan, Carlton and Ali, 2004; Bennet and Lockyer, 2004; Jaffee, 2003; Barker, 2002; Goodyear, Salmon, Spector, Steeples and Tickner, 2001, McMann, 1994). These roles prevail regardless of the type of learning environment; traditional or online method, and thus suggesting that these roles may be distinct from each other in terms of its characteristics (Bennett and Lockyer, 2004; Goodyear et al, 2001; McMann, 1994). For instance, the design of the subject content and the technical role attribute in a traditional learning environment may differ from the one in an e-learning context. It is thus fair to claim that the four roles may have their own unique attributes in terms of skill complexity, autonomy, significance, identity and level of feedback. As suggested by Hackman and Oldham (1976, 1980), each job has its own attributes and the level of attributes may differ from one employee to another. Given the complexity of teaching, instead of examining the "whole teaching job" attributes, the present study sought to examine the attributes of the four major roles that make up the "whole teaching job". The following section explains further the individual roles of teachers in both environments; traditional and e-learning.

\subsubsection{Pedagogical Role}

Miller and King (2003) noted that the key to success in any course, whether technology-based or not, is the instructors' pedagogical skill. Being a teacher, the person is responsible to explain, provide reinforcement and support, make announcements, gives directions, discipline students and many others that are related to imparting to students what the teacher possesses. In the traditional environment, most instructions are given face-to-face. There are human contact and personal touch from the instructors. The presence of verbal communication such as intonation and nonverbal communication like body language help to enrich the conveyance of messages. A teacher can always use different verbal and nonverbal communication style to express his or her opinion, to give remarks to students or even to encourage students to interact in the classroom. Such a luxury is absent in an online tutorial. Nonverbal communication like eye contact, gestures, facial expressions and other body languages are not visible to students. And most importantly, students are feeling isolated due to limited physical interaction. According to Newble and Cannon (1994), an instructor who uses the same approach in an online class will face difficulty as he has to find alternative ways to overcome the absence of nonverbal communication.

\subsubsection{Managerial Role}

According to Sadker and Sadker (1991), an effective teacher must also be a good manager who is able to organize the academic content and instruction. Educators are no longer focusing on controlling student behavior, instead they have 
moved to creating and maintaining an environment that supports learning (Evertson and Harris, 1992). Franklin (1988) and Hanson (1991) contend that teachers strongly feel that they are qualified to organize the learning process according to their own method. Despite the impersonal school rules that regulate the academic processes, once the teachers enter the classroom, the learning facilitation will accord their methods as they deem fit.

On the other hand, Flakes, Kuhs, Donnelly and Ebert (1995) mentioned the importance of time management to an instructor. Time management is about setting the timeframe to plan, implement and evaluate the course. The need to manage time is even more important in e-learning as students are given the freedom to be independent and the amount of face-to-face meetings is rather limited. In order to keep students on track, a structured schedule indicating important activities such as online or face-to-face discussion, meetings and deadlines must be planned ahead and communicated to students. The fact that students are geographically dispersed makes managing the course even more challenging.

Major significant difference between traditional and e-learning in respect of class management is mainly contributed by the type of technology used to facilitate the learning processes and activities. In the traditional environment, when the physical interaction is there, the instructors can always communicate and remind the students on the activities of the course. But in e-learning environment, the instructors have to rely on various tools such as electronic bulletin board and email to communicate messages to students about new activities, feedback on students' work, changes and latest update.

\subsubsection{Technical Role}

Given the various techniques and media, instructors need to choose the one that is most appropriate depending on the learning outcomes, practicality and the costs to develop or to use the method. Being the one who determines which technology or tools to be used in the classroom, the instructor should be able to assist and guide the students in using the equipment in such a way that facilitate learning. Inability to provide necessary assistance will lead to frustration among students. Everett (1998) points out that students' motivation to learn partly depends on their ability to persevere with technical problems and how these problems are resolved. Goodyear et al (2001) assert that instructors should have adequate technical skills and understand the capabilities and limitations of available technologies and tools.

In e-learning, Barker (2002) mentioned that online instructors should have the ability to use a range of different tools such as email, word processor, spreadsheet, database and Web page authoring tools. Bennet and Lockyer (2004) added that online instructors should develop skills to create and integrate electronic subject resources. Miller and King (2003) stressed that the instructor should be competent in using the technology so that he can decrease students' anxiety during the course and address technology issues that might arise.

\subsubsection{Subject Designer Role}

Jaffee (2003) who wrote on the transformation of pedagogical style from traditional environment to Web-based approach noted that in the former environment, the instructor will play as the 'sage on the stage' whose task is to actively deliver and the students to passively receive the information. Student-centered learning however, requires the students to be actively involved and be given the opportunity to apply their own understanding about the subject in order to come up with new ideas or knowledge. Under this environment, the course design should allow interactivity, collaboration and reflection. It also requires the instructor to rethink the course outcomes, content, assignments, supporting materials and evaluation methods. Bennet and Lockyer (2004) stated that the designer role of instructors in both settings; traditional and online, is basically the same. Instructors need to develop the overall design, identify assessment tasks and plan a sequence of activities and specific resources. In online settings, the instructors are expected to do more in order to make use of technology by integrating it in their designer roles to enhance learning. Here, the ability of instructors to design the course in such a way that creates learning and the same time utilizing the available resources is crucial.

\section{Research Methodology}

\subsection{Samples and Data Collection}

All public and private institutions of higher learning in Malaysia were identified and samples were drawn from faculties/department of interest. In each faculty, lecturers were chosen using simple random sampling. As this study was about teaching roles and responsibilities, only those academic staff or faculty members who have a teaching load of at least 50 percent of their total work load were included in the study.

Questionnaires were distributed through online, regular mail and personal visits. Online survey yielded the lowest response rate (only 80 online responses) and thus regular mail survey had to be employed. This method generated 137 responses. The subsequent method used was to personally distribute the questionnaire and this technique resulted in 75 responses. In total, 292 responses were collected and it took about 6 months to complete. 


\subsection{Measurement Instruments and Statistical Techniques}

Prior studies examining the influence of technology on the roles of instructor mainly used qualitative research method. This study chose to employ a quantitative approach which could provide empirical evidence about technology influence. In this study, the levels of technology was operationalized using several sources such as Gavin (2003), Fallon and Brown (2003) and, Roberts and Jones (2000). These scholars suggested several levels of e-learning technology ranging from the lowest to the most sophisticated technology. In this study, we added a new level that indicates a stage of learning that uses traditional method with minimum or no technology application. This traditional stage of learning precedes the lowest e-learning method. Table 1 below describes the five levels of technology used in teaching.

The four teaching role attributes (pedagogical, managerial, technical and subject designing) were measured using the items in the Job Diagnostic Survey (JDS) developed by Hackman and Oldham (1980). Each teaching role attribute was measured using 15 items adopted from the JDS that reflect skill variety, task significance, task identity, autonomy and knowledge of work results. All the items are expressed on 7-point scales, where 1 is low and 7 is high. Brief explanations on each of the four roles were provided to ensure respondents understood the survey objectives and to make it clear to the potential respondents that they were required to evaluate the role characteristics individually based on the 15 items. The other section of the questionnaire asked for the demographic information of the respondents.

Statistical Package for the Social Sciences (SPSS) 15.0 for Windows was used to analyze the data. Pearson correlation tests and one-way ANOVA test were used to examine the relationships between variables.

\section{Data Analysis}

\subsection{Respondents' Demographic Analysis}

A total of 292 university instructors participated in the survey. The majority of the respondents were from public universities (47 percent, 28 percent were from private university colleges, 23 percent from private universities and the rest ( 2 percent) were from public university colleges. In terms of teaching experience, $29 \%$ of the instructors had more than 11 years, 36 percent have between 6 to 10 years and 35 percent have 1 to 5 years. Out of the 292 respondents, 176 of them (60 percent) possessed Master degree, 20 percent with doctorate, and 20 percent with bachelor degree. Majority of the respondents were from the age group of 30 to 39 years old (52 percent), $21 \%$ in age group of 40 to 49 years, 20 percent were between 20 to 29 years old and only 7 percent were those above 50 years of age.

\subsection{Factor Analysis and Reliability Tests}

The factor analysis output on the sixty items that measured instructors' four teaching role attributes resulted in 11 factors, which explained $71.21 \%$ of the total variance. The Bartlett test of sphericity is significant and that the Kaiser-Meyer-Olkin measure of sampling adequacy is 0.917 which was far greater than 0.6. Inspection of the anti-image correlation matrix revealed that all the measures of sampling adequacy were well above the acceptable level of 0.5 . In selecting items for each scale, two criteria were used. First, items on a single factor with factor loading of .3 or less were dropped (Hair et al, 1998), and second to improve scale reliability, items with less than 0.3 item-to-total correlations were deleted from the scales (Nunnally, 1978).

The factor analysis output indicated unclear cut factor loadings and the items did not appropriately loaded in the expected groups. Several factors were found containing items from different teaching roles. Nevertheless, for the sake of the present study, regardless of the dimensionality, four factors with items which indicate common teaching role were used and seven others were dropped as they did not provide meaningful interpretation. Despite the high loadings, since all the items within the respective factors did not appropriately loaded in the expected group, all these factors had to be dropped for further analyses. Subsequently, reliability tests were conducted to measure the Cronbach's coefficient alpha for each factor items. Factor 1 consisted 10 items was labeled subject design role attributes with Cronbach's coefficient alpha of 0.936 . Factor 2 that contained 8 items was named pedagogical role attributes and the reliability coefficient for the scale was 0.907. Factor 3 was labeled technical role attributes had 6 items with Cronbach's coefficient of 0.885 . Factor 5 consisted of 8 items with reliability coefficient of 0.894 was labeled managerial role attributes.

\subsection{Analysis of Variance across Different Technology Levels}

One-way ANOVA tests were used to determine if there exist significant differences of role attributes in terms of technology used by the respondents. Based on the output in Table 2, significant difference was only found in technical role attributes across the five levels of technology $(\mathrm{F}=4.289, \mathrm{p}=0.002)$. It could be concluded that technology level used by instructor exerted an influence on the technical role attributes for at least 2 of the 5 technology levels. However, the effects of technology level on pedagogical role attributes, managerial role attributes, and subject design role attributes were found to be insignificant.

A post hoc multiple comparisons was carried out to examine which level of technology significantly influenced technical role attributes. The results of the Tukey's test indicated that traditional users had significantly different 
technical role attributes means with medium technology users (mean difference of $-0.52511, \mathrm{p}=0.014)$. Tukey's test also showed a significant difference between traditional level and pure e-learning users (mean difference of -1.47348, $\mathrm{p}=0.022$ ). There were no significant differences in technical role attributes between traditional and low technology users as well as between traditional and high technology users. Table 4.6 details the result.

\subsection{Correlations between Technology Levels and the Four Teaching Roles Attributes}

The relationships between technology levels and the four role attributes were assessed using Pearson Product Moment correlation as shown in Table 3 below.

As shown in Table 3, two role attributes (managerial role attributes and technical role attributes) were found to be significant and positively related to technology levels. The correlation between managerial role attributes and technology levels had an r-value of 0.122 and p-value of 0.019. A significant positive relationship was also found between technology level and technical role attributes with an $r$-value of $0.215(p=0.000)$. Technology levels were not significantly related to pedagogical role attributes and subject design role attributes. Despite the insignificant relationship, however, it was observed that technology level was negatively related to the two role attributes.

\section{Discussion of Findings}

The study's findings generally did not support the notion that there exist differences in terms of teaching role attributes across different technology levels used by instructors. The teaching role attributes in pedagogical, managerial and subject-design role did not indicate any significant differences despite the diverse levels of technology applied. The findings were inconsistent with the ideas proposed by most scholars that asserted that these three roles should differ significantly in terms of their degree of characteristics (Newble and Cannon, 1994; Mason, 1991; Kerr, 1986, Goodyear et al., 2001). However, significant differences were found in different technology levels in terms of technical role attributes. The significant difference captured in this study conformed to the views of the majority of scholars (Bennet and Lockyer, 2004; Goodyear et al., 2001; Miller and King, 2003; Kerr, 1986; Davie and Palmer, 1985). The findings further indicated that users of traditional technology for teaching were significantly different from those in medium and pure e-learning technologies. The former group of users was found to have relatively lower scores of technical attributes. Thus, it could be inferred that the higher the level of technology used in teaching, the higher would be the degree of characteristics in the technical aspect.

The insignificant findings in the other three teaching role attributes across the 5 levels of technology revealed an interesting fact. Despite the diverse technology used in their teaching practices, instructors do not differ much in terms of their pedagogical, managerial and subject design role attributes. This may be due to the fact that in most Malaysian higher learning institutions which are committed to adopting various technologies in teaching and learning, the major emphasis is only to ensure that they have the systems that enable information gathering, management, access, and communication in various forms (Hassan, 2002). The other crucial aspects like upgrading ICT knowledge and skills as well as redesigning the instructors' jobs are neglected. With less emphasis in those aspects, the instructors fail to acknowledge the fact that there are significant differences between the traditional teaching method and the technology-based methods.

Other major findings obtained by the study are the relationships between the four teaching role attributes and the technology level. The findings showed that only managerial and technical role attributes are significantly related to technology levels and the relationships are positive. The significant findings suggest that the higher the level of technology employed by instructors, the higher the degree of attributes in managerial and technical aspects of their teaching job. The findings are consistent with the majority views that state the more sophisticated the technology used in the teaching job, the higher would be the demand to manage instructors' job. Better management of communication among students in e-learning particularly in monitoring the flow of conversation, encouraging comments, synchronizing and handling information overload (Zafeiriou, 2000). In terms of the influence of technology levels on technical aspects of the job, the positive significant relationship signified that the higher the technology levels, the more would be the degree of technical aspect required from the job. This is also in line with the opinions that the higher level of technology used, the more would be the technical skills and competence required among the instructors (Bennet and Lockyer, 2004; Goodyear et al., 2001; Miller and King, 2003; Kerr, 1986; Davie and Palmer, 1985).

A possible explanation for the insignificant relationship between pedagogical and subject design roles lies in the fact that technology adopted by educational institutions is done without proper assessment on the needs and readiness of the instructors. Instructors may have low awareness in their changing roles in these two aspects and thus resulting in the old ways of doing things.

\section{Implications of the Study on Policy Makers}

The study's findings have three major implications relevant to policy makers in higher educational institutions and national regulatory bodies. First, to deal with lack of knowledge and skills among instructors in using higher technology in teaching, needs assessment has to be conducted to determine the type of training instructor needs with respect to their 
readiness and competencies. Second, attention must be directed towards re-examining the instructors' jobs that involve higher technology use. Failure to redesign the job in accordance with the type of technology used would render the lecturers having low awareness of how their teaching job should change. Finally, there should be a clear link between the changing natures of teaching job with the performance evaluation scheme. Without clear association between the nature of the job and the reinforcement scheme, lecturers are unlikely to acknowledge the fact that they have to change the way they perform in line with the teaching methods used.

\section{Conclusion}

This study provides a better understanding about the impact of technology on teaching roles. The emphasis on the four teaching roles is timely given the diverse impacts that technology has on the role attributes. Based on the findings, policy makers could benefit by examining how the teaching job could be redesigned and re-evaluated. As for future research implications, further studies could be carried out to examine how non-teaching aspects like such research and publication as well as administrative duties are affected by technology.

\section{References}

Agbonlahor, R.O. (2006). Motivation for use of information technology by university faculty: A developing country perspective. Information Development, 22(4), 263-277.

Barker, P. (2002). Skill sets for online teaching. In ED MEDIA 2002 World Conference on Educational Multimedia, Hypermedia \& Telecommunications Proceedings, Denver.

Bartel, A., Ichniowski, C., \& Shaw, K. (2007). How does information technology affect productivity? Plant-level comparisons of product innovation, process improvement, and worker skills. The Quarterly Journal of Economics, 122(4), 1721-1758.

Bennet, S., \& Lockyer, L. (2004). Becoming an online teacher: Adapting to a changed environment for teaching and learning in higher education. Educational Media International, 41(3), 231-244.

Berge, Z.L. (2008). Changing instructor's roles in virtual worlds. The Quarterly Review of Distance Education, 9(4), 407-414.

Braverman, H. (1974). Labor and monopoly capital, New York: Monthly Review Press.

Davie, L., \& Palmer, P. (1985). Computer-teleconferencing for advanced distance education. Canadian Journal of University Continuing Education, 11(2), 56-66.

Everett, D. R. (1998). Taking instruction online: The art of delivery. Proceedings of SITE 98: Society for Information Technology and Teacher Education International Conference, Washington, DC, March 10-14, 1998.

Evertson, C. M., \& Harris, A. H. (1992). What we know about managing classrooms. Educational Leadership, 49(7), 74-77.

Fallon, C., \& Brown, S. (2003). E-learning standards: A guide to purchasing, developing, and deploying standards conformant e-learning. Florida: St. Lucie Press.

Flake, C. L., Kuhs, T., Donnelly, A., \& Ebert, C. (1995). Reinventing the role of teacher: Teacher as researcher. Phi Delta Kappan, 76(5), 405-407.

Gavin, T. (2003). Industry Report. Training, pp $21-45$.

Glenn, E. N., \& Feldberg, R. L. (1977). Degraded and De-Skilled: The proletarianization of clerical work. Social Problems, 25, 56-64.

Goodyear, P., Salmon, G., Spector, J. M., Steeples, C., \& Tickner, S. (2001). Competences for online teaching: A special report. Educational Technology, Research \& Development, 49(1), 65-72.

Gratton-Lavoie, C., \& Stanley, D. (2009). Teaching and learning principles of Microeconomics online: An empirical assessment. Journal of Economic Education, Winter, 3-25.

Hacifazlioglu, O., Sacli, O.A., \& Yengin, I. (2005). Lecturers' attitudes towards the use of technology: Alternative strategies for faculty administrators. In Proceedings of the Second International Conference on eLearning for Knowledge-Based Society, August 4-7, Bangkok.

Hackman, J. R., \& Oldham, G. R. (1976). Motivation through the design of work: Test of a theory. Organizational Behavior and Human Performance, 16, 250-279.

Hackman, J. R., \& Oldham, G. R. (1980). Work redesign. Addison-Wesley Publishing Co.

Hair, J.F., Anderson, R.E., Tatham, R.L., \& Black, W.C. (1998). Multivariate data analysis, New Jersey: Prentice Hall.

Hanson, E. M. (1991). Educational administration and organizational behavior. Boston: Allyn and Bacon. 
Hanson, J. (2003). Encouraging lecturers to engage with new technologies in learning and teaching in a vocational university: The role of recognition and reward. Higher Education Management and Policy, 15(3), 135-149.

Jaffee, D. (1997). Asynchronous learning: Technology and pedagogical strategy in a distance learning course. Teaching Sociology, 25(4), 262-277.

Jaffee, D. (2003). Virtual transformation: Web-based technology and pedagogical change. Teaching Sociology, 31(2), 227-236.

Kewell, B., \& Beeby, M. (2003). Student and lecturer responses to the introduction of computer assisted learning (CAL) in a university business school. Teaching in Higher Education, 8(3), 413-430.

Kraft, P. (1977). Programmers and managers. New York: Springer-Verlag.

Laurillard, D. (2006). E-learning in higher education. In P. Ashwin (Ed.), Changing Higher Education: The Development of Learning and Teaching (1-12). London: Routledge.

Marlia, P. (2007). E-learning in Malaysian public universities: Case studies of Universiti Kebangsaan Malaysia and Universiti Teknologi Malaysia. In Proceedings of the $1^{\text {st }}$ International Malaysian Educational Technology Convention, November 2-5, Johor Bharu, Malaysia.

Mason, R. (1991). Moderating educational computer conferencing. DEOSNEWS, 1(19).

Menzies, H. (1982). Women and the chip: Case studies of the effects of informatics on employment in Canada. Montreal: The Institute for Research on Public Policy.

Miller, T. W., \& King, F. B. (2003). Distance education: Pedagogy and best practices in the new millennium. International Journal Leadership in Education, 3(3), 283-297.

Ministry of Higher Education Malaysia. (2007). Statistik IPTA. [Online] Available: http://www.mohe.gov.my (June 27, 2007)

Mitchell, R.L.G. (2009). Online education and organizational change. Community College Review, 37(1), 81-101.

Neo, M., \& Neo, T. (2009). Engaging students in multimedia-mediated constructivist learning - Students' perceptions. Educational Technology \& Society, 12(2), 254-266

Newble, D., \& Cannon, R. A. (1994). A handbook for teachers in universities \& colleges: A guide to improving teaching methods. London: Kogan Page.

Nunnally, J.C. (1978). Psychometric Theory. New York: McGraw-Hill.

Poon, W. C., Low, L. T., \& Yong, G. F. (2004). A study of web-based lLearning (WBL) environment in Malaysia. The International Journal of Educational Management, 18(6), 374-385.

Roberts, T. S., \& Jones, D. T. (2000). Crossroads of the new millennium: Four models of online teaching. Proceedings of the Technological Education and National Development Conference on the April 8-10, Abu Dhabi, UAE.

Ryan, M., Carlton, K. H., \& Ali, N. S. (2004). Reflections on the faculty in distance learning and changing pedagogies. Nursing Education Perspectives, 25(2), 73-80.

Sadker, M. P., \& Sadker, D. M. (1991). Teachers, schools, and society. New York: McGraw-Hill.

Shaiken, H. (1984). Work transformed: Automation and labor in the computer age. New York: Holt, Rinehart and Winston.

Shen, R., Wang, M., \& Pan, X. (2008). Increasing interactivity in blended classrooms through a cutting-edge mobile learning system. British Journal of Educational Technology, 39(6), 1073-1086.

Siragusa, L., \& Dixon, K.C. (2006). A research methodology: The development of survey instruments for research into online learning in higher education. Issues in Educational Research, 16(2), 206-225.

Zafeiriou, G. (2000). Students' perceptions of issues arising from and factors influencing group interaction in computer conferencing: A grounded theory approach. Unpublished doctoral thesis, University of Sheffield, UK.

Zimbalist, A. (Ed.). (1979). Case studies on the labor process. New York: Monthly Review.

\section{Acknowledgement}

$\mathrm{B}$ dea is to give training to employees for the new responsibility and requirement task created - that equence they have to fo.

The authors would like to acknowledge the contributions of Prof Dr M. Saeed Siddiq and Assoc Prof Dr Ravindran Ramasamy during the completion of the study. 
Table 1. Measuring the Level of Technology Use among Instructors

\begin{tabular}{|c|c|}
\hline $\begin{array}{l}\text { Independent } \\
\text { Variable: } \\
\text { Level of } \\
\text { Technology }\end{array}$ & $\begin{array}{l}\text { Descriptions: } \\
\text { In performing my role as a teaching instructor... }\end{array}$ \\
\hline Traditional & $\begin{array}{l}\text {... I use no / very minimal computer applications or other related technology. We use } \\
\text { face-to-face meetings and teaching aids used are like white/blackboard, overhead } \\
\text { projector, and printed handouts/documents. }\end{array}$ \\
\hline $\begin{array}{l}\text { Low } \\
\text { technology }\end{array}$ & $\begin{array}{l}\text {... sometimes I use word processing, power point presentation and Internet. I only use } \\
\text { face-to-face meetings and asynchronous communication channels. I do not use } \\
\text { synchronous communication channels at all. }\end{array}$ \\
\hline $\begin{array}{l}\text { Medium } \\
\text { technology }\end{array}$ & $\begin{array}{l}\text {...I use word processing, power point presentation and Internet. I use both synchronous } \\
\text { and asynchronous communication channels. Learning materials are available to students } \\
\text { at our institution's website and also in digital forms. Face-to-face meetings are still } \\
\text { extensively used. }\end{array}$ \\
\hline $\begin{array}{l}\text { High } \\
\text { technology }\end{array}$ & $\begin{array}{l}\text {...I use word processing, power point presentation and Internet. I use both synchronous } \\
\text { and asynchronous communication channels. Learning materials are available to students } \\
\text { at our institution's website and also in digital forms. Face-to-face meetings are conducted } \\
\text { only when necessary. }\end{array}$ \\
\hline $\begin{array}{l}\text { Pure } \\
\text { e-learning }\end{array}$ & $\begin{array}{l}\text {...I only use synchronous and asynchronous communication channels. Students are } \\
\text { learning independently. Learning materials are available to students at our institution's } \\
\text { website and also in digital forms. There is no face-to-face meeting at all. }\end{array}$ \\
\hline
\end{tabular}

Sources: Adapted from: (1) Fallon, C. and Brown, S. (2003) E-Learning Standards: A Guide to Purchasing, Developing, and Deploying Standards Conformant E-Learning, St. Lucie Press: Florida. (2) Gavin, T. (2003) "Industry Report", Training, 21 - 45. (3) Roberts, T. S. and Jones, D. T. (2000) "Crossroads of the New Millennium: Four Models of Online Teaching," TEND 2000 in Proceedings of the Technological Education and National Development Conference on the April 8-10, Abu Dhabi, UAE. 
Table 2. Analysis of Variance of Instructors' Roles Attributes Across Five Levels of Technology

\begin{tabular}{|c|c|c|c|c|c|c|}
\hline & & $\begin{array}{l}\text { Sum of } \\
\text { Squares }\end{array}$ & df & $\begin{array}{l}\text { Mean } \\
\text { Square }\end{array}$ & $\mathrm{F}$ & Sig. \\
\hline \multirow{3}{*}{$\begin{array}{l}\text { Pedagogical role } \\
\text { attributes }\end{array}$} & Between Groups & 5.432 & 4 & 1.358 & 2.024 & .091 \\
\hline & Within Groups & 192.517 & 287 & .671 & & \\
\hline & Total & 197.949 & 291 & & & \\
\hline \multirow{3}{*}{$\begin{array}{c}\text { Managerial role } \\
\text { attributes }\end{array}$} & Between Groups & 5.191 & 4 & 1.298 & 2.175 & .072 \\
\hline & Within Groups & 171.248 & 287 & .597 & & \\
\hline & Total & 176.439 & 291 & & & \\
\hline \multirow[t]{3}{*}{$\begin{array}{l}\text { Technical role } \\
\text { attributes }\end{array}$} & Between Groups & 14.813 & 4 & 3.703 & 4.289 & .002 \\
\hline & Within Groups & 247.791 & 287 & .863 & & \\
\hline & Total & 262.605 & 291 & & & \\
\hline \multirow[t]{3}{*}{$\begin{array}{c}\text { Subject design role } \\
\text { attributes }\end{array}$} & Between Groups & 5.045 & 4 & 1.261 & 1.309 & .267 \\
\hline & Within Groups & 276.616 & 287 & .964 & & \\
\hline & Total & 281.662 & 291 & & & \\
\hline
\end{tabular}

Table 3. Relationship between Technology Levels and the Four Teaching Role Attributes

\begin{tabular}{|cc|c|c|c|c|}
\hline & $\begin{array}{c}\text { Pedagogical } \\
\text { role attributes } \\
\text { role attributes }\end{array}$ & $\begin{array}{c}\text { Managerial } \\
\text { attributes }\end{array}$ & $\begin{array}{c}\text { Subject } \\
\text { design role } \\
\text { attributes }\end{array}$ \\
\hline $\begin{array}{c}\text { Technology } \\
\text { level }\end{array}$ & $\begin{array}{c}\text { Pearson } \\
\text { Correlation } \\
\text { Sig. (1-tailed) } \\
\mathrm{N}\end{array}$ & -.002 & $.122\left(^{*}\right)$ & $.215\left(^{* *}\right)$ & -.062 \\
& .483 & .019 & .000 & .147 \\
\end{tabular}

